\title{
Współczesna architektura sakralna Kościoła katolickiego - przestrzeń Eucharystii w środowisku kulturowym
}

\author{
Jan Rabiej ${ }^{1}$ \\ Politechnika Śląska \\ jan.rabiej@polsl.pl (D) https://orcid.org/0000-0001-5398-5323
}

Geneza architektury sakralnej Kościoła katolickiego wskazuje na ideał świątyni integralnie wkomponowanej w kontekst kulturowy. W ewolucji wzorów świątyń chrześcijańskich następowało scalanie pierwiastków tradycji i nowoczesności ${ }^{2}$. Istotę tego fenomenu streszcza stwierdzenie Soboru Watykańskiego II: „Świat spotkał się z Kościołem, a Kościół ze światem”3. Reguł kształtowania katolickiej architektury sakralnej nie określają kanony czy estetyczne wzory - Kościół nie uznaje żadnego ze stylów za własny. Otwartość Kościoła rzymskiego poszerza horyzont poszukiwań właściwych form i znaczeń również dla współczesnych świątyń.

Akcentowanie przez Sobór Watykański II afirmującej obecności Kościoła katolickiego w zmieniającym się świecie było odpowiedzią na przeobrażenia kulturowe inspirowane przez dwudziestowieczny modernizm. Przeorientował on świadomość społeczeństw ewolucyjnie kształtowanych przez stulecia. Zmienił stosunek człowieka do wartości, które na przestrzeni wieków zachowywały absolutny i uniwersalny charakter. Modernistyczny kult ahistorycznej nowoczesności wyznaczył nowe kryteria kształtowania idealnego środowiska życia człowieka. Teoretyczne wzorce modernistycznego miasta

1 Prof. dr hab. inż. arch. Jan Rabiej, pracownik naukowo-dydaktyczny Wydziału Architektury Politechniki Śląskiej w Gliwicach, kierownik Katedry Teorii, Projektowania i Historii Architektury. Prace projektowo-twórcze realizuje w ramach autorskiej pracowni Atelier 8. Zainteresowania autora wytycza postrzeganie architektury jako fenomenu kulturowego, który łączy właściwości dzieła techniki z walorami dzieła sztuki. Przedmiot opracowań teoretycznych ma bezpośredni związek z jego pracami projektowo-twórczymi. Autor około 50 samodzielnych publikacji naukowych, projektant 12 zrealizowanych obiektów architektonicznych (zespoły sakralne, zespoły mieszkalne, budynki biurowe, zakłady produkcyjne), ponad 30 wnętrz architektonicznych, kilkudziesięciu projektów witraży, kompozycji malarskich i rzeźbiarskich.

2 J. Rabiej, Tradycja i nowoczesność w architekturze kościołów katolickich. Świątynia fenomenem kulturowym, Gliwice 2004 (Zeszyty Naukowe Politechniki Śląskiej, 1606).

3 E. E. Y. Hales, Papież Jan XXIII i jego rewolucja, Warszawa 1967, s. 9. 
odzwierciedlały przeobrażenia w sferze celów ludzkich dążeń - również tych, które zachowały religijne odniesienia. Zasadniczo zmieniło się miejsce świątyń w modernistycznej rzeczywistości. Ich kształty i znaczenia przejęte z wzorców historycznych nie przystawały do nowoczesnej sytuacji. Skutkiem modernistycznego przełomu stało się ożywienie poszukiwań formuły świątyni odpowiadającej zmieniającym się uwarunkowaniom kulturowym.

Otwarcie na współczesne uwarunkowania - przy jednoczesnym pogłębieniu świadomości własnej tradycji - określiły nową transkulturową perspektywę w kształtowaniu świątyń chrześcijańskich. Jej wyrazem są budowle sakralne powstające nie jako absolutne dominanty wyznaczające porządek przestrzenny i znaczeniowy krajobrazu kulturowego, ale integralnie w niego wpisane założenia architektoniczne służące kultowi religijnemu oraz wielorakim funkcjom pozawyznaniowym odpowiadającym potrzebom wielokulturowych społeczności (ilustracje 1-3).

\section{Współczesna architektura sakralna wobec kryzysu kultury}

Uwarunkowania kulturowe przełomu XX i XXI wieku, w których ewoluuje katolicka architektura sakralna, ulegają głębokim przeobrażeniom. Z jednej strony postulat inkulturacji - szczególnie nośny pod wpływem skutków procesu globalizacji - rodzi obawy o synkretyczne zrelatywizowania prawd wiary. Z drugiej strony powszechność (katolickość) Kościoła - identyfikowana $\mathrm{z}$ walorami uniwersalizmu - konfrontowana jest $\mathrm{z}$ obawami o zacieranie wyrazistości wyznaniowej. Kontrowersje te - wpływające na kryteria kształtowania współczesnych świątyń - są wyrazem kryzysu kultury. Stan ideowego „zagmatwania” obejmuje uniwersalne znaczenia, wartości - odnoszące się również do rzeczywistości sacrum. Wrażliwość na jej transcendentne walory osłabia podważanie sensu antynomii sacrum-profanum. Sacrum „zubożone” do sfery emocji jest dostępne niemal bez ograniczeń. Przejawem tego „upowszechnienia” jest swobodna asymilacja symboli czy atrybutów sakralności we wszelkich obszarach środowiska kształtowanego przez człowieka. Oswajamy się stopniowo z charakterystycznymi formami budowli, aranżacjami wnętrz czy poszczególnymi elementami ich wyposażenia, które wymiennie spotykamy w kościołach, salach koncertowych, muzeach, galeriach handlowych, ośrodkach rekreacyjno-wypoczynkowych, a także w naszych mieszkaniach. Poprzez tak kształtowaną percepcję przestrzeni zatracamy 
poczucie ścisłej identyfikacji tzw. przestrzeni sakralnej ze sferą doświadczeń religijnych. Skutkiem tych przewartościowań jest swobodne kreowanie przestrzeni parasakralnych. Są one zrelatywizowanymi wyrazami metafizycznej orientacji natury człowieka, którą charakteryzuje antropologiczna kategoria homo religiosus.

Próby redefinicji pojęć sacrum, przestrzeń sakralna, architektura sakralna komplikuje szerzący się proces desakralizacji budowli kultu religijnego. „Wygasanie” religijnego sensu świątyń jest przejawem sekularyzacji. W jej następstwie liczne kościoły stają się kłopotliwymi nieruchomościami, których wartość zredukowana zostaje do pustostanów skazywanych do rozbiórki lub przekształceń na funkcje świeckie. O kierunku tych wyborów decydują głównie względy ekonomiczne. Ich prymat niesie zagrożenia, których skutkami stają się deformacje zabytków architektury, a nawet nieodwracalne zaprzepaszczenia unikalnych walorów dziedzictwa kulturowego. Procesy desakralizacji realizowane w zgodzie z regułami chroniącymi przed profanacją czy dewastacją prowadzą niejednokrotnie do spektakularnych „sukcesów”. Realizacje oryginalnych projektów rewitalizacji przywracają kulturze historyczne kościoły w postaci np. sal koncertowych, bibliotek czy galerii sztuki Równocześnie w nie mniej wartościowych wnętrzach opuszczonych świątyń aranżuje się ekskluzywne hotele, prywatne rezydencje, stylowe restauracje lub wielkopowierzchniowe bazary, skateparki, a nawet nocne kluby...

Paradoksalnie stan zagubienia towarzyszący kształtowaniu nowych, współczesnych budowli sakralnych oraz ochronie świątyń istniejących jest źródłem różnorodności architektury kościołów naszych czasów. W cieniu spektakularnych aktów sekularyzacji, desakralizacji, laicyzacji nadal powstają w przestrzeni miast miejsca kultu religijnego, którym Kościół katolicki nadaje formy kaplic, oratoriów, parafialnych zespołów sakralnych, klasztorów wspólnot zakonnych, katedr biskupich czy monumentalnych świątyń - pomników.

\section{2. „Kościoły naszych czasów” - „uspołecznienie Kościoła”}

Sylwety kościołów wyróżniające się w panoramach współczesnych miast nie są jedynymi formami emanacji religijnego wymiaru $\mathrm{w}$ przestrzeni kulturowej. Niewielkie wspólnoty religijne tworzą rozproszoną w strukturze

4 J. Rabiej, Architektura. Sztuka transfiguracji, Gliwice 2013. 
miast siatkę kaplic - oratoriów wkomponowanych w zabudowę z funkcjami świeckimi. Pełnią one funkcje ośrodków wyznaniowych o zróżnicowanym stopniu dostępności. Pod względem architektonicznym są to najczęściej założenia włączone w większe, wielofunkcyjne obiekty lub kompleksy zabudowy o złożonym programie użytkowym. O usytuowaniu w nich miejsc kultu religijnego świadczą akcenty w postaci symboli religijnych lub elementy informacji wizualnej. $\mathrm{W}$ tych formach przestrzeni sakralnych pozbawionych znamion monumentalności, realizowanych w zminimalizowanej skali, sąsiedzko przenikających się ze strefami zamieszkania, nauki czy pracy jest urzeczywistniana idea „uspołecznienia Kościoła” (ilustracje 4-5).

Formuła kościoła katolickiego, którego wymiar religijny zachowuje ścisłą integralność z kontekstem społecznym, odzwierciedla istotę chrześcijańskiej wizji pełni życia. Sens budowania tego typu miejsc kultu religijnego warunkuje świadomość lokalnej wspólnoty wyznawców Chrystusa, dla których centrum życia jest Eucharystia - liturgia ofiary i dziękczynienia obejmująca i afirmująca wszystkie jego przejawy. W konsekwencji przestrzeń kościoła nie jest sferą sytuowaną „ponad” innymi obszarami środowiska codziennej egzystencji, ale w jego wnętrzu. Mieszczące się w niej liczne komplementarne funkcje i posługi wyznaczają jego znaczenie jako wielofunkcyjnego, otwartego domu, schroniska, przystani. Jest w nim - obok miejsca przeznaczonego na sprawowanie liturgii i medytację - również przedszkole, biblioteka, świetlica, jadalnia... (ilustracje 6-8).

Różnorodne formy „uspołecznionego kościoła” zostały w ostatnim półwieczu upowszechnione szczególnie w krajach zachodniej Europy, w Skandynawii i w Stanach Zjednoczonych ${ }^{6}$. Ich układy urbanistyczne i kształty architektoniczne podporządkowane są założonym programom funkcjonalnym, które odzwierciedlają wielorakie przejawy zaangażowania wspólnot religijnych w działania wychowawcze, charytatywne, edukacyjne i kulturalne podejmowane na rzecz lokalnych społeczności. W tym zakresie zarysowały się odmienności wyróżniające programy i formy architektoniczne zespołów zabudowań parafialnych we Francji, Niemczech, Szwajcarii, Włoszech, Holandii czy Belgii. We Francji, gdzie Kościół ożywiają tzw. „małe grupy”, spotykamy liczne kameralne ośrodki pozbawione monumentalnej retoryki. W Niemczech

5 J. Dahinden, Kirchenbau - Zeichen für was?, „Kunst und Kirche” 41 (1978), s. 121.

6 M. E. Rosier-Siedlecka, Odpowiedź przestrzenna na nowe założenia liturgii i duszpasterstwa. Przegląd nowych kościołów Europy Zachodniej, [w:] Sacrum i sztuka, oprac. N. Cieślińska, Kraków 1989, s. 72-84. 
i na obszarach niemieckojęzycznych Szwajcarii w centrach parafialnych obok kościoła sytuuje się wielofunkcyjne sale służące alternatywnym programom np. dla młodzieży. Przy parafiach tych funkcjonują kluby dla osób starszych, przedszkola, ogólnodostępne biblioteki i czytelnie. Współczesne obiekty sakralne Włoch stały się szczególnie interesujące ze względu na ich walory kompozycyjne - zwłaszcza rozwiązania przestrzenne wkomponowane w złożone warunki krajobrazowe. Odmienną wrażliwością charakteryzują się nowoczesne ośrodki parafialne realizowane na terenach Holandii i Belgii. Ujmuje w nich formalna powściągliwość, autentyczność środków zapewniająca poczucie harmonii, równowagi, spokoju.

Wśród mnogiej liczby katolickich zespołów sakralnych powstałych w miastach europejskich na przełomie XX i XXI wieku trudno o wyczerpującą charakterystykę jednego wiodącego wzorca - ideału. Wymowną ilustracją spojrzenia na miejsce kultu religijnego we współczesnym środowisku miejskim jest zespół sakralny zbudowany w peryferyjnej dzielnicy Rzymu - Tor Tre Teste. Przykład ten charakteryzuje katolicką architekturę sakralną u schyłku drugiego tysiąclecia dziejów chrześcijaństwa. Pozostaje ona znakiem rzeczywistości nadprzyrodzonej, a jednocześnie jest osadzana w realiach lokalnych wspólnot, często pasywnych religijnie i zdezintegrowanych społecznie. O otwartości tej koncepcji zadecydowały założenia programowe sformułowane przez jej inicjatorów oraz okoliczności jej realizacji. Projekt architektoniczny zespołu sakralnego został wyłoniony w ramach konkursu zorganizowanego przez wikariat rzymski dla upamiętnienia obchodów Świętego Roku 2000. Do udziału w nim zaproszono czołowych współczesnych architektów reprezentujących odmienne tradycje kulturowe i religijne. Byli to T. Ando, G. Behnisch, S. Calatrava, P. Eisenmann, F. O. Gehry, R. Meier. Pierwiastkiem łączącym wszystkie projekty konkursowe był wyraźnie uwypuklony w nich wymiar wspólnototwórczy - społeczny kościoła. W komentarzu autorskim Richarda Meiera do projektu nagrodzonego realizacją czytamy: „Jak wskazano w warunkach konkursu, jego głównym celem jest reintegracja i naprawa odizolowanego i zdegradowanego osiedla i jego społeczności. Kościół pomyślano w opozycji do izolacji miejsca. Został zaprojektowany jako miejsce samo w sobie, częściowo święte, częściowo świeckie, ma dopomóc mieszkańcom w znalezieniu swego miejsca w świecie. W dużej mierze czyni to przez sposób, w jaki umożliwia wspólnocie reprezentację w procesie rytuału, zabawy i celebracji. [...] W planowaniu kościoła i centrum z ich dziedzińcami mieliśmy na uwadze poglądy H. G. Gaddamera o fundamentalnej roli gry, zabawy i rytuału 
we wszelkich formach kultury. [...] Powstała zatem koncepcja zespołu jako miejsca formalnej i nieformalnej odświętnej celebracji: symboliczne upamiętnienie ofiary Chrystusa odbywać się będzie przez modlitwę i zorkiestrowanie ludzkiego ruchu"7.

Idee zawarte w każdej z konkursowych koncepcji Kościoła Roku Świętego 2000 - mimo wielu towarzyszącym im formalnym oryginalnościom - okazały się mocno osadzone w trwałej tradycji Kościoła. Odnajduje on swoje miejsce w zmieniającym się świecie, podążając drogą afirmacji i ewolucji, nie zaś poprzez negację historycznej ciągłości i rewolucyjny ferment. Kształty współczesnych kościołów pozostają odbiciem złożonej rzeczywistości kulturowej. Jej podmiotem i jednocześnie kreatorem jest człowiek, dla którego naturalnym i optymalnym środowiskiem życia jest akceptująca go społeczność. Stąd kościół, jeśli ma być przestrzenią prawdziwie przychylną człowiekowi, winien być miejscem otwartym, gościnnym, bezpiecznym, kreatywnym, zdrowym... ekologicznym. Trudno zatem oczekiwać, by współczesna architektura sakralna wyznaczała kierunki spektakularnych przełomów, których łaknie współczesny człowiek wypatrujący wciąż nowych i coraz mocniejszych wrażeń. Wizja świątyni, niezmiennie odnosząca się do rzeczywistości transcendentnej, zachowuje wciąż znamiona obrazujące aspiracje, możliwości, ale i ograniczenia społeczności, które ją tworzą. Dlatego również Kościół Roku Świętego 2000 - wbrew oczekiwaniom inicjatorów i twórców kościołów - nie przyniósł jakościowego przełomu w dziedzinie chrześcijańskiej architektury sakralnej. Skalę wydarzenia epokowego przyjął natomiast fakt powstania w samej aglomeracji Rzymu kilkudziesięciu innych nowych kościołów upamiętniających Rok Święty 2000. Wśród nich zespół sakralny na Tor Tre Teste stał się jubileuszowym pomnikiem wiary Kościoła, którego wierni w chrześcijaństwie odkrywają na nowo korzenie swej kulturowej tożsamości (ilustracje 9-11).

\section{Współczesna architektura kościołów katolickich w Polsce}

Upowszechniane w krajach zachodniej Europy wzorce „uspołecznienia Kościoła” znalazły swoje odzwierciedlenie również w programach funkcjonalnych i architektonicznych kształtach licznych zespołów sakralnych zbudowanych w ostatnich dziesięcioleciach w Polsce. W okresie przed

7 R. Meier, Estetyka logiki, tłum. M. A. Urbańska, „Architektura i Biznes” 1996 nr 7-8, s. 11-13. 
transformacją ustrojową z roku 1989 - w uwarunkowaniach politycznych podporządkowanych ateistycznej presji władz komunistycznych - kościoły spychane były na „margines” oficjalnych form funkcjonowania społeczeństwa. Z pokonywaniem propagandowych i administracyjnych utrudnień wiązało się uzyskiwanie pozwoleń na ich budowę. Lokalizacje nowych kościołów najczęściej wskazywano w miejscach peryferyjnych - na obrzeżach osiedli, w oderwaniu od logiki relacji urbanistycznych. Ograniczeniami obejmowano skalę i zakres funkcjonalny budowli sakralnych. W tych okolicznościach wiele nowych kościołów powstawało na przekór piętrzonym trudnościom, w atmosferze konspiracyjnego pośpiechu, częstokroć według niespójnych założeń. W oderwaniu od tych uwarunkowań trudno zrozumieć fenomen „wielkiej fali” budownictwa sakralnego w PRL-u.

W licznych kościołach z tego okresu znajdujemy wymowną ilustrację „otwarcia”, jakie z inspiracji Soboru Watykańskiego II dokonało się w katolickiej architekturze sakralnej. Obok przykładów powielających wzorce historyczne powstawały budowle, których istota tkwi w spójnym przenikaniu funkcji liturgicznej z innymi funkcjami wspólnototwórczymi. Przyjmowały one postać szeroko dostępnych zespołów parafialnych. Trwałe zalążki społecznej roli Kościoła tworzyły się w trakcie budowy w trudnych okolicznościach wielorakich ograniczeń. Tę znamienną zależność charakteryzują dzieje kościołów wzniesionych w tamtym okresie w podkrakowskiej Nowej Hucie. Arka w Bieńczycach czy symboliczna świątynia w Mistrzejowicach zostały wpisane w historię dramatycznych wydarzeń z lat 80. jako „oazy” wolnej myśli. W ich murach znajdowali schronienie prześladowani politycznie twórcy kultury. Aranżowane w ich przestrzeniach koncerty, wystawy, spektakle, odczyty były inspirującymi przykładami dla wielu innych form społecznej aktywności w ówczesnych kościołach, które stawały się miejscami kulturotwórczego oddziaływania.

Otwarcie na zewnątrz - w szerokie oddziaływanie o charakterze wychowawczym, charytatywnym, edukacyjnym, kulturowym, a nawet usługowym charakteryzują zespoły sakralne budowane w Polsce na przełomie XX i XXI wieku. Cechy „uspołecznienia” przyjął np. zespół sakralny pw. Matki Kościoła Niepokalanej Jutrzenki Wolności konsekrowany w 2001 roku w KatowicachBrynowie. Jego ostateczny kształt jest rezultatem szeregu zmian dokonanych w pierwotnym projekcie w trakcie budowy. Projekt koncepcyjny założenia - wybrany w drodze konkursu architektonicznego - zakładał połączenie funkcji parafii katolickiej z ośrodkiem formacyjnym Ruchu Światło-Życie. 
W kilkuletnim okresie budowy nastąpiły okoliczności, które skłoniły do istotnych korekt funkcjonalnych i architektonicznych w obrębie budynku kościoła, przekształceń programowych w segmentach zabudowań parafialnych oraz zmian w układzie urbanistycznym. W stanie aktualnym w zespole sakralnym - obok kościoła i rotundy z kaplicą - mieszczą się różnorodne funkcje: probostwo, diecezjalny dom rekolekcyjny, Muzeum Misyjne, ośrodek duszpasterstwa trzeźwości, biuro podróży i oddział poczty. Kompleks kubatur z wkomponowanym w nie plenerowym amfiteatrem scalają elementy urbanistyczne: drogi komunikacji kołowej z zespołami parkingów, trakty piesze, otwarte place, skwery zieleni urządzonej. W sylwecie tego założenia centralne miejsce zajmuje bryła kościoła. Jest ona ideowo-formalnym rdzeniem również w skali obejmującej zabudowę najbliższego otoczenia. Architektura tego zespołu sakralnego zachowuje przymioty przestrzeni - środowiska, w którym dokonuje się integracja wymiaru religijnego z wymiarem społecznym ${ }^{8}$ (ilustracje 12-13).

Zespół sakralny Franciszkanów budowany od 2000 roku w Tychach nawiązuje do tradycji lokowania klasztorów żebraczych wewnątrz miejskiego środowiska. Miejscem jego usytuowania stał się teren graniczący z zespołami zabudowy mieszkaniowej. Kompozycję planu kompleksu budowli szczelnie wypełniających nieregularną działkę wyznaczają kontury kościoła w kształcie krzyża św. Franciszka. Forma ta ma czytelne odzwierciedlenie zarówno w warstwie funkcjonalnej budowli, jak i w jej sylwecie. Oryginalność tego założenia wyznaczają przenikające się w jego architekturze walory tradycji i nowoczesności. O głębokim osadzeniu w tradycji nie decydują jednak bezpośrednie odniesienia do wzorów historycznych chrześcijańskich świątyń, ale ich twórcze reinterpretacje. Układ przestrzenny założenia kształtują różnorodne motywy, w których rozpoznajemy nawiązania do kamiennej, historycznej zabudowy miast włoskich - z ich pierzejami krętych uliczek i wertykalnymi akcentami wież. Bezpośrednim nawiązaniem do wzorów franciszkańskiej architektury jest wkomponowana w bryłę budowli kopia kaplicy Porcjunkula z Asyżu. Wymownym wyrazem związków wznoszonej świątyni z tradycją architektury sakralnej średniowiecza jest kamienny

8 Realizacja zespołu sakralnego pw. Matki Kościoła Niepokalanej Jutrzenki Wolności w Katowicach otrzymała tytuł Najlepszego Obiektu Katowic 2001, została nagrodzona Wyróżnieniem II stopnia w Ogólnopolskim Konkursie Stowarzyszenia Architektów Polskich w kategorii obiektów architektonicznych zrealizowanych w 2001 roku oraz Medalem za Wybitne Dzieło Architektoniczne Zrealizowane w Roku 2001 przyznanym przez Stowarzyszenie Architektów Polskich w 2002 roku. 
budulec - dolomit pozyskiwany z pobliskich złóż w okolicach Libiąża. Bloki kamienne docinane na placu budowy, pieczołowicie dopasowywane do elementów żelbetowych konstrukcji, ręcznie układane nabywają metafizycznej godności. W powolnym budowaniu zamierzonym na wiele lat dokonuje się symboliczny akt twórczy realizowany według spójnej idei, bez pośpiechu, zgodnie z pulsem czasu, bez egzaltacji, na miarę zaangażowania parafian i ich materialnych zasobów. Prace budowlane pod nadzorem architekta, mieszkańca parafii, realizuje jeden z zakonników z pomocą nielicznej grupy ochotników. Nowy klasztor Franciszkanów w Tychach wyrasta na dzieło niepowtarzalne - jednocześnie się rodzi, dojrzewa i starzeje. W jego przestrzeni tworzy się nowe „centrum” dzielnicy. Jest ono częścią środowiska, w którym kształtowana jest tożsamość lokalnej społeczności (il. 14-15).

\section{Podsumowanie}

Przy wznoszeniu współczesnych kościołów - podobnie jak nasi poprzednicy z minionych wieków - stajemy w obliczu niepowtarzalnego zadania, którego sensem jest budowa domu Bożego ściśle wkomponowanego w środowisko, gdzie żyje wspólnota wiernych - tu i teraz. To, co powinno być stałe, niezmienne, ponadczasowe w kształtach naszych świątyń streszczają artykuły Katechizmu Kościoła Katolickiego:

Liturgia jest szczytem, do którego zmierza działalność Kościoła, i jednocześnie jest źródłem, z którego wypływa cała jego moc (1074).

Liturgię celebruje cała wspólnota, Ciało Chrystusa zjednoczone ze swoją głową. Czynności liturgiczne nie są czynnościami prywatnymi, lecz kultem Kościoła, będącego „sakramentem jedności” (1140).

Liturgia Kościoła przyjmuje, integruje i uświęca elementy stworzenia i kultury ludzkiej, nadając im godność znaków łaski nowego stworzenia w Jezusie Chrystusie (1149).

Widzialne kościoły nie są zwyczajnymi miejscami zgromadzeń, ale oznaczają i ukazują Kościół żyjący w tym miejscu, mieszkanie Boga z ludźmi pojednanymi i zjednoczonymi w Chrystusie (1180).

Dom modlitwy, gdzie sprawuje się i przechowuje Najświętszą Eucharystię [...] winien być schludny, sposobny do modlitwy i świętych uroczystości (1181). 
Świątynia jest szeroko otwartym i gościnnym domem wszystkich dzieci Bożych (1130).

Świadomość tych zasad chroni twórców, budowniczych i użytkowników kościołów przed powierzchownym kopiowaniem wzorców epok minionych bądź urzeczywistnianiem w nich ideałów inspirowanych głównie ambicjami, subiektywnymi gustami czy modnymi stylizacjami. Architektura sakralna w Kościele katolickim służy głównie Eucharystii. Wszystko, co składa się na materialny kształt „kościołów naszych czasów”, współtworzy przestrzeń Eucharystii, w której ogniskują się wszelkie przejawy życia toczącego się w jej środowisku.

\section{Abstrakt}

\section{Współczesna architektura sakralna Kościoła katolickiego - przestrzeń Eucharystii w środowisku kulturowym}

Fenomen architektury sakralnej Kościoła katolickiego wynika z jej integralnego wkomponowania w ewoluujący kontekst kulturowy. Postulaty Soboru Watykańskiego II dotyczące budowli sakralnych akcentują ich „otwarcie” na wymiar społeczny środowiska, w jakim są sytuowane. Takie ujęcie reguł odnoszących się do twórczości w zakresie architektury sakralnej tłumaczy brak uzasadnienia dla tworzenia arbitralnego wzorca - ideału - kanonu kościoła katolickiego. Różnorodność architektury współczesnych zespołów sakralnych w Europie Zachodniej, Skandynawii i Stanach Zjednoczonych odzwierciedla odmienności założeń ideowo-funkcjonalnych, które odpowiadają potrzebom, aspiracjom i możliwościom budujących je lokalnych społeczności. Analogiczne zakresy uwarunkowań decydują o specyfice architektury kościołów katolickich w Polsce. Prymat kryteriów liturgicznych i społecznych nad kryteriami formalno-stylistycznymi w kształtowaniu architektury sakralnej jest źródłem inspiracji w poszukiwaniu nowych koncepcji „kościołów naszych czasów”.

Słowa kluczowe: architektura sakralna; środowisko kulturowe; eucharystia

\section{Abstract}

\section{Contemporary Catholic Architecture: A Space for the Eucharist in the Cultural Environment}

The phenomenon of Catholic religious architecture results from its integral integration with an evolving cultural context. The proposals of the Second Vatican Council concerning religious buildings emphasize their "openness" to the social dimension of the environment in which they are found. Such a conception of rules referring to religious architecture explains the lack of a rationale for creating an arbitrary ideal or a model for a canonical Catholic church. The architectural diversity of contemporary sacred ensembles in Western Europe, Scandinavia, and the United States reflects the distinct ideological and functional assumptions that respond to the needs, aspirations, and resources of local communities that build them. Analogous conditions determine the architectural uniqueness of Catholic churches 
in Poland. The dominance of liturgical and social criteria over formal and stylistic criteria in shaping sacred architecture is a source of inspiration in the search for new concepts of "churches for our age."

Keywords: sacred architecture; cultural environment; Eucharist

\section{References}

Dahinden, J. (1978). Kirchenbau - Zeichen für was? Kunst Und Kirche, 41.

Hales, E. E. Y., \& Życieńska, E. (1968). Papież Jan XXIII i jego rewolucja. Warszawa-Kraków: Biblioteka „Więzi”, Znak. Meier, R. (1996). Estetyka logiki. Architektura i Biznes, (7-8), 11-13.

Rabiej, J. (2004). Tradycja i nowoczesność w architekturze kościołów katolickich. Świątynia fenomenem kulturowym. Gliwice: Wydawnictwo Politechniki Śląskiej.

Rabiej, J. (2013). Architektura. Sztuka transfiguracji. Gliwice: Wydawnictwo Politechniki Śląskiej.

Rosier-Siedlecka, M. E. (1989). Odpowiedź przestrzenna na nowe założenia liturgii i duszpasterstwa. Przegląd nowych kościołów Europy Zachodniej. In N. Cieślińska (Ed.), Sacrum i sztuka (pp. 72-84). Kraków: Wydawnictwo Znak. 


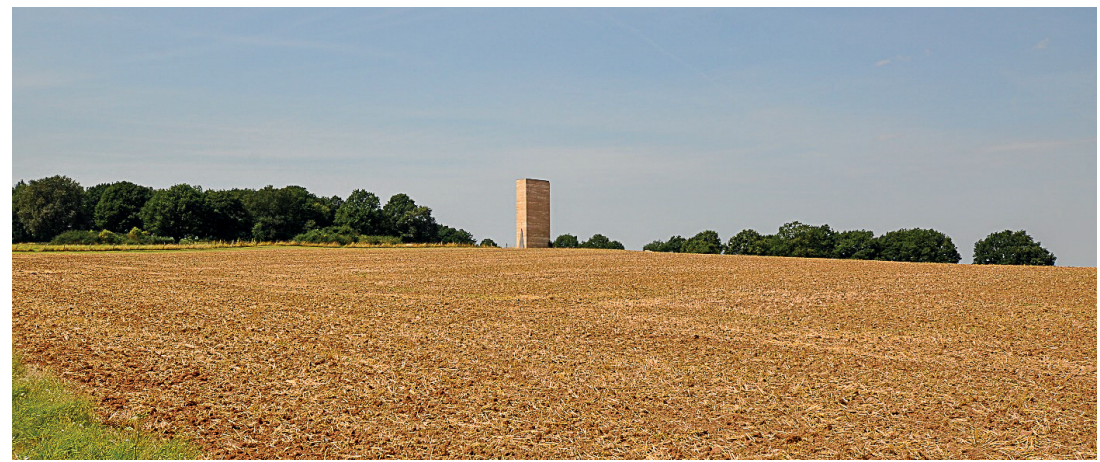

1. Kaplica Brata Klausa w Mechernich - proj. arch. P. Zumthor

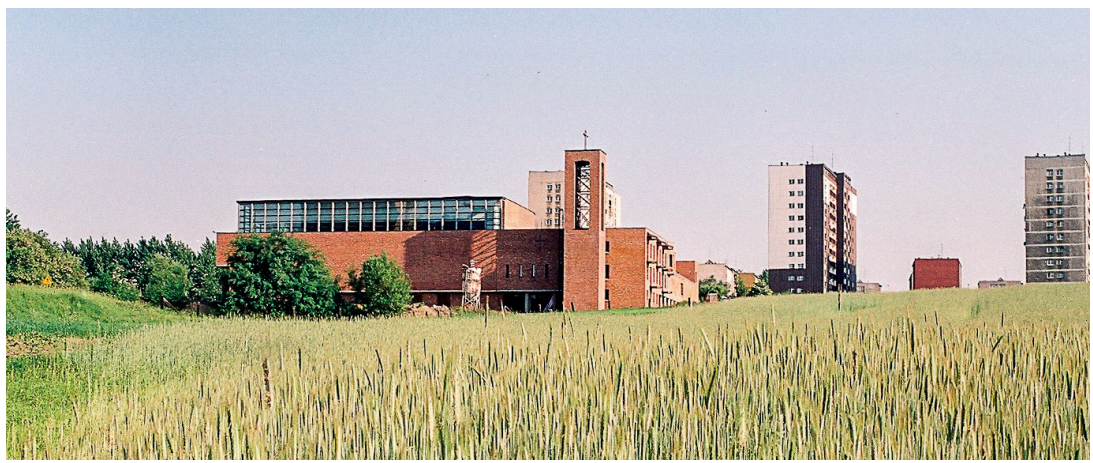

2. Zespół sakralny pw. NMP Matki Kościoła w Gliwicach - proj. arch. M. Polak, M. Bielski

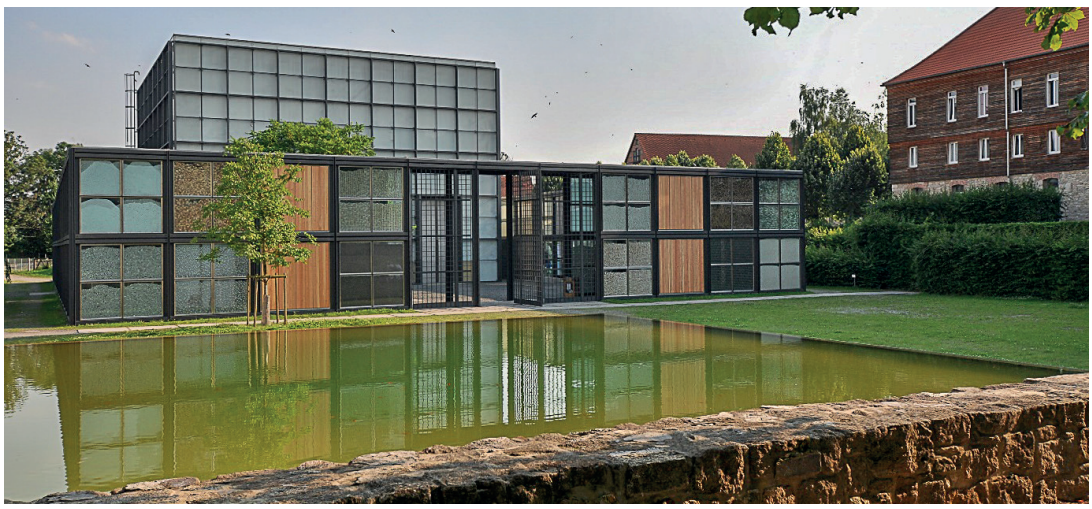

3. „Pawilon Chrystusa” z wystawy EXPO 2000 w Europejskim Centrum Formacji Młodzieży na terenie historycznego założenia klasztoru Cystersów w Volkenroda - proj. arch. Gerkan, Marg und Partner 


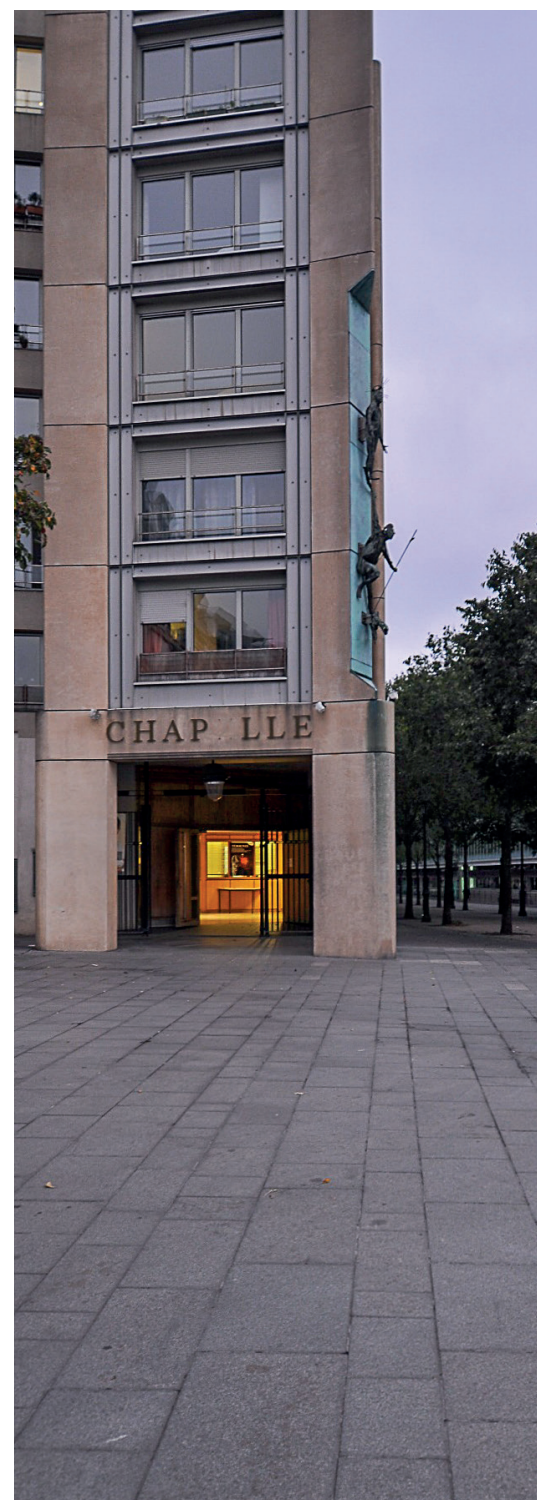

4. Katolicka kaplica De L’Agneau de Dieu w Paryżu

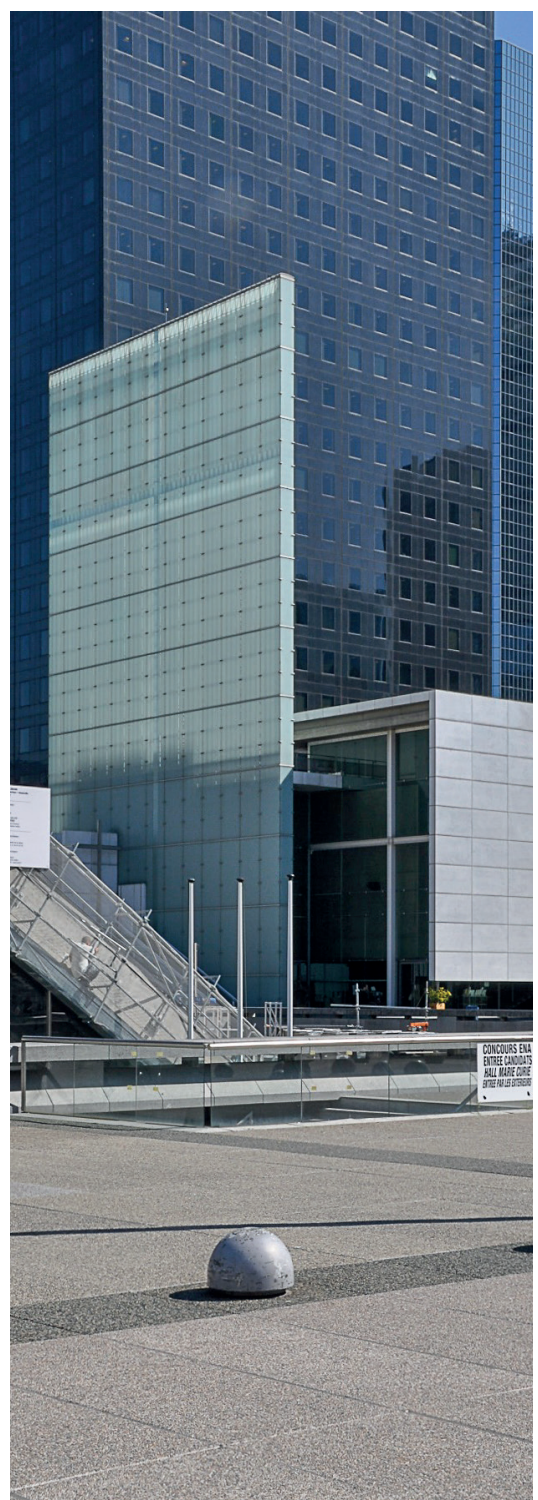

5. Katolicka kaplica Notre-Dame de la Pentecôte w paryskiej dzielnicy La Défense proj. arch. F. Hammouténe 


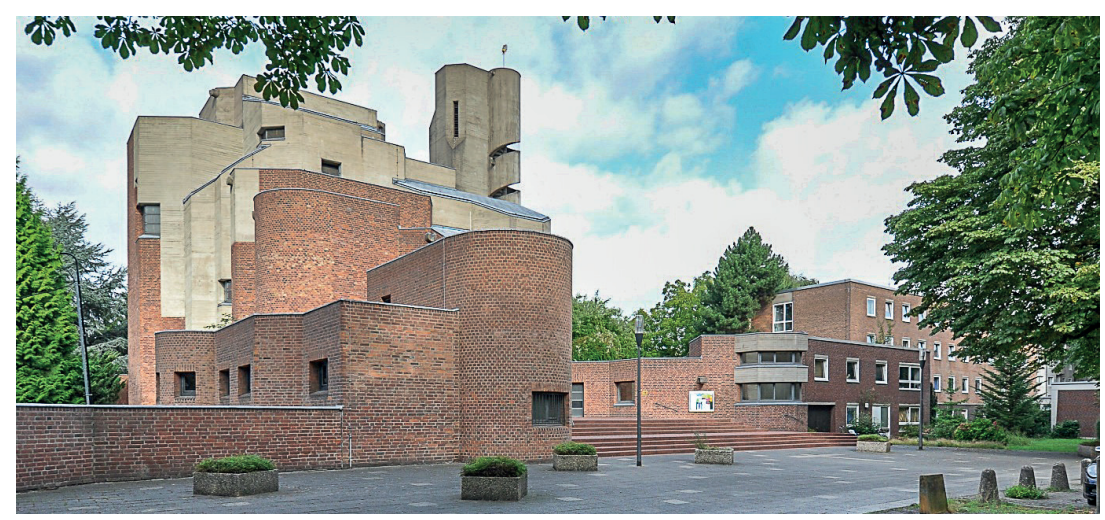

6. Kościół pw. Zmartwychwstania Jezusa Chrystusa w Kolonii-Lindenthal - proj. arch. G. Böhm

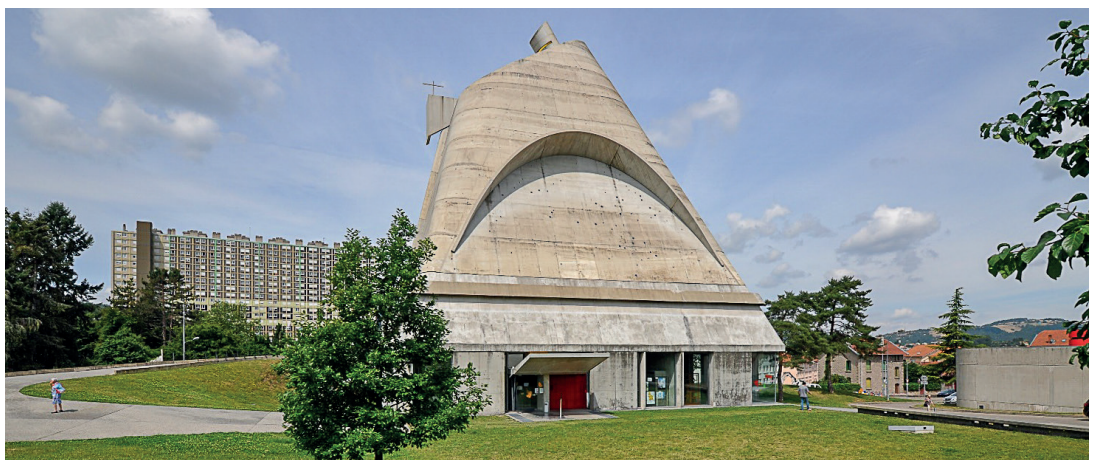

7. Kościół pw. św. Piotra w Firminy - proj. arch. Le Corbusier

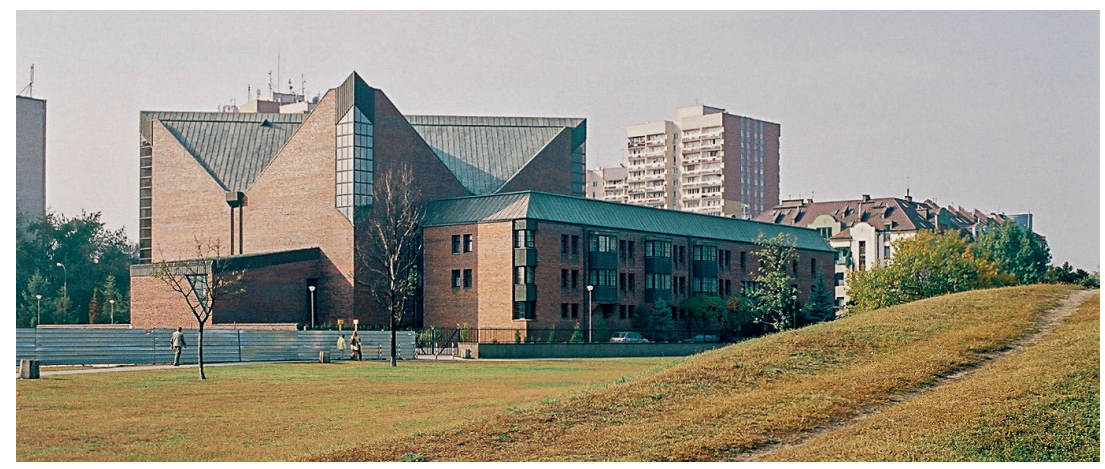

8. Kościół pw. Nawrócenia św. Pawła Apostoła w Warszawie proj. arch. K. Kucza-Kuczyński, A. Miklaszewski, B. Osiński 

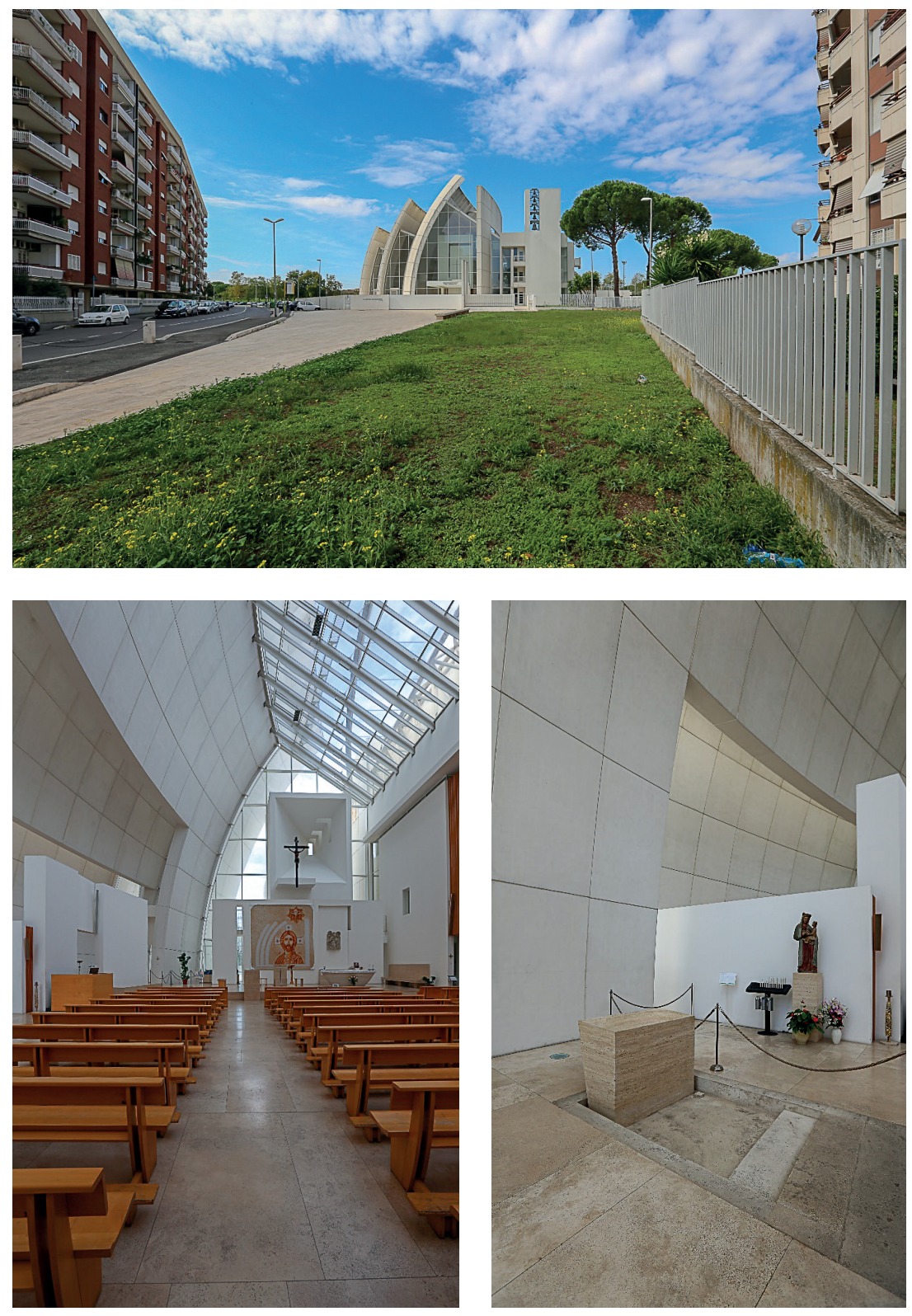

9-11. Kościół Roku Świętego 2000 w Rzymie - proj. arch. Richard Meier 

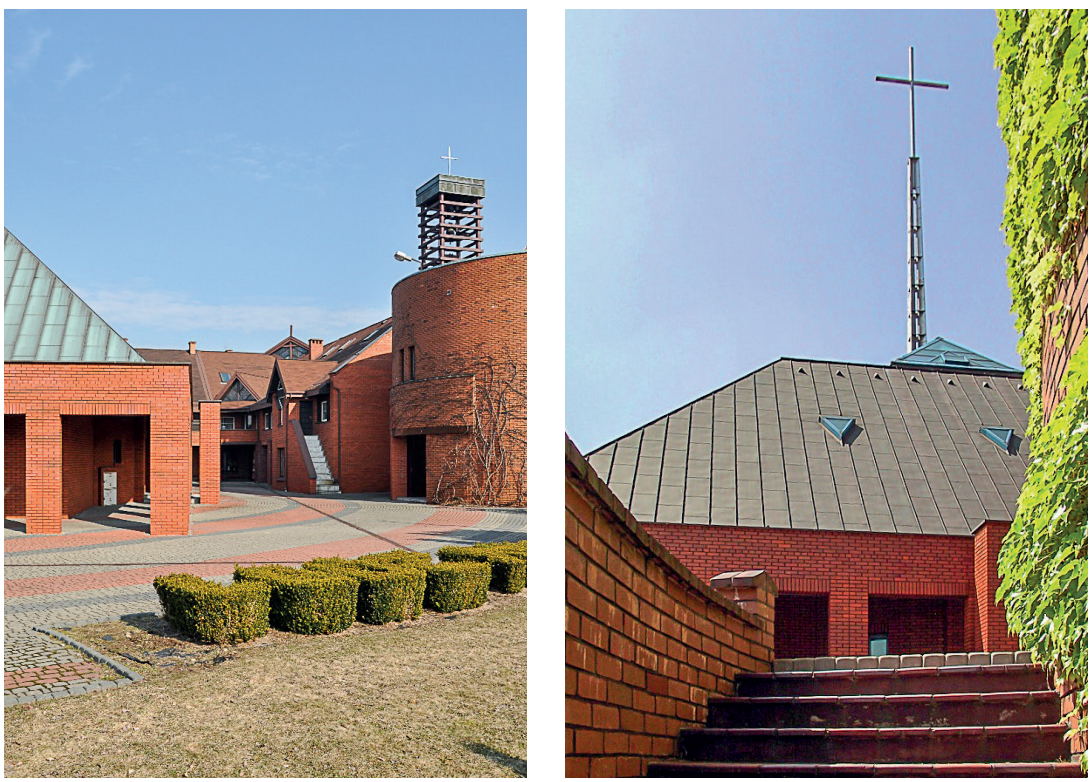

12-13. Zespół sakralny pw. Matki Boskiej Niepokalanej Jutrzenki Wolności w Katowicach proj. arch. A. Gałkowski, A. Lekka-Gałkowska, T. Czerwiński, J. Rabiej
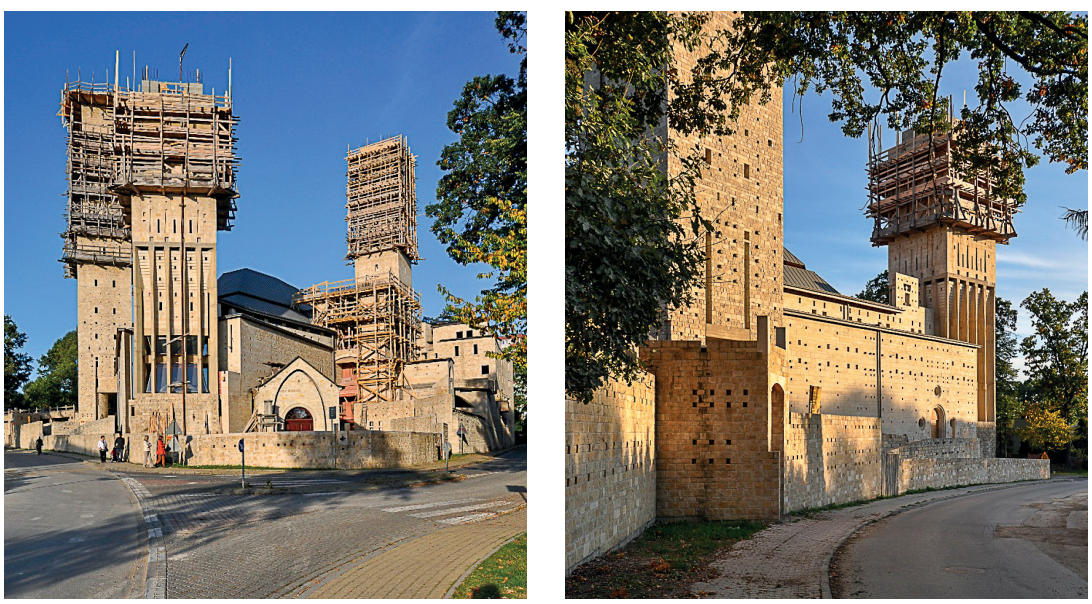

14-15. Zespół sakralny pw. św. Franciszka i św. Klary w Tychach - proj. arch. S. Niemczyk 